\title{
Pharmaceutical Potential of Synthetic and Natural Pyrrolomycins
}

\author{
Stella Cascioferro ${ }^{1,2, *}$, Maria Valeria Raimondi ${ }^{1}$, Maria Grazia Cusimano ${ }^{1, *}$, Demetrio Raffa ${ }^{1}$, \\ Benedetta Maggio $^{1}$, Giuseppe Daidone ${ }^{1}$ and Domenico Schillaci ${ }^{1}$
}

Received: 16 October 2015 ; Accepted: 24 November 2015 ; Published: 4 December 2015

Academic Editor: Peter J. Rutledge

1 Dipartimento di Scienze e Tecnologie Biologiche, Chimiche e Farmaceutiche—Sezione di Chimica e Tecnologie Farmaceutiche-Università degli Studi di Palermo, Via Archirafi 32, Palermo 90123, Italy; mariavaleria.raimondi@unipa.it (M.V.R.); demetrio.raffa@unipa.it (D.R.); benedetta.maggio@unipa.it (B.M.); giuseppe.daidone@unipa.it (G.D.); domenico.schillaci@unipa.it (D.S.)

2 IEMEST, Istituto Euromediterraneo di Scienza e Tecnologia, Via Emerico Amari, 123, Palermo 90139, Italy

* Correspondence: stellamaria.cascioferro@unipa.it (S.C.); mariagrazia.cusimano@unipa.it (M.G.C.); Tel.: +39-091-23891920 (S.C.); +39-091-23891914 (M.G.C.)

\begin{abstract}
The emergence of antibiotic resistance is currently considered one of the most important global health problem. The continuous onset of multidrug-resistant Gram-positive and Gram-negative bacterial strains limits the clinical efficacy of most of the marketed antibiotics. Therefore, there is an urgent need for new antibiotics. Pyrrolomycins are a class of biologically active compounds that exhibit a broad spectrum of biological activities, including antibacterial, antifungal, anthelmintic, antiproliferative, insecticidal, and acaricidal activities. In this review we focus on the antibacterial activity and antibiofilm activity of pyrrolomycins against Gram-positive and Gram-negative pathogens. Their efficacy, combined in some cases with a low toxicity, confers to these molecules a great potential for the development of new antimicrobial agents to face the antibiotic crisis.
\end{abstract}

Keywords: pyrrolomycins; antibiotic resistance; antibiofilm agents; pyoluteorin; pentabromopseudilin

\section{Introduction}

Antibiotic resistance of common pathogenic microorganisms is a topic of great concern that has finally attracted the attention of mass-media and governments. Drug-resistant bacteria are responsible for some 30,000 deaths per year in the UK and Europe and it is estimated that 23,000 people in the United States die from pathogens that are not susceptible to treatment with any of the current antibiotics [1]. There is therefore an urgent need to introduce novel antimicrobial molecules in therapy, and there are several possible alternative strategies to conventional antibiotics to counteract antibiotic resistance [2-6].

No new chemical classes of broad-spectrum antibiotics and few molecules with narrow spectrum have been found in the recent past [7]. The increase of antimicrobial resistance has stimulated research aimed towards the discovery of inhibitors of new bacterial targets [8,9]. In addition, more than $80 \%$ of infections are associated to the growth of a sessile community of pathogenic bacteria, the so-called biofilms, which are intrinsically resistant to conventional antibiotics [10].

Conventional antibiotics are effective against planktonic cells but are usually ineffective against biofilm-associated infections because of the high level multi-factorial resistance provided by biofilm mode of growth [11].

The development of anti-biofilm drugs, or the discovery of antibiotics with this additional property, may contribute to combat the emergence of antibiotic-resistance. 
The reconsideration of old molecules that were previously largely replaced by more "modern" antibiotics might represent a rapid strategy for the treatment of drug-resistant infectious diseases $[12,13]$. Valuable examples are provided by colistin, a polymixin produced by Paenibacillus polymyxa subspecies colistinus [14,15], or temocillin, fosfomycin, mecillinam, nitrofurantoin and chloramphenicol for multi drug resistant (MDR) Gram-negative bacteria, and trimethoprim-sulfamethoxazole for methicillin-resistant Staphylococcus aureus (MRSA) [16]. Furthermore, some authors have recently suggested the use of tetracyclines for multidrug-resistant Acinetobacter baumannii infections [17].

Many antimicrobial molecules have been discovered in the past, but they were never developed for clinical practice. These include natural halogenated pyrroles antibiotics, such as pyoluteorin, discovered in 1958, and the pyrrolomycins, isolated in 1983.

Here, we will comment on the possibility that some of these old molecules are valuable therapeutic agents to defeat the widespread emergence of bacterial resistance, placing emphasis upon their profile of efficacy, safety, and tolerability. We will specifically describe the pyrrolomycins, a class of polyhalogenated pyrrolic compounds, endowed with potent antibacterial activity, particularly against Gram-positive, and, in some cases, Gram-negative pathogens, including Pseudomonas aeruginosa, and showing the ability to target biofilms.

\section{Halogenated Pyrroles Related to Pyrrolomycins}

The antibacterial properties of halogenated pyrroles, such as pentabromopseudilin (1), isolated from the marine bacterium Alteromonas luteoviolaceus, and pyoluteorin (2) isolated from Pseudomonas aeruginosa (Figure 1), both structurally related to pyrrolomycins, have been known for a long time.

Burkholder et al. described in 1966 the antibiotic properties of pentabromopseudilin, (2,3,4-tribromo-5(1'-hydroxy, 2',4'-dibromophenyl)pyrrole, 1) [18]. The antibacterial activity of pentabromopseudilin is due to its ability to interfere with the synthesis of macromolecules in Gram-positive and Gram-negative bacteria, probably through the formation of a prototropic isomer by hydrogen shift and elimination of hydrogen bromide. This reaction proceeds with the formation of a quinonoid system 3 (Figure 1) that may bind $\mathrm{SH}$ or NH groups of the target proteins.<smiles>Oc1c(Br)cc(Br)cc1-c1[nH]c(Br)c(Br)c1Br</smiles><smiles>O=C(c1cc(Cl)c(Cl)[nH]1)c1c(O)cccc1O</smiles><smiles>O=C1C(Br)=CC(Br)=CC1=C1N=C(Br)C=C1Br</smiles>

3<smiles>O=C(c1cc(Br)cc(Br)c1O)c1[nH]c(Br)c(Br)c1Br</smiles>

4

Figure 1. Structures of compounds 1-4.

Although there are different biological activities described for this molecule, such as antifungal and antitumor activity, inhibition of cholesterol biosynthesis, and plant protection [19], here we specifically focus on the antibacterial activity, considering this class of old compounds as a good 
starting point to thwart the worldwide prevalence of antibiotic-resistant pathogens and the lack of novel antibiotics. The antibacterial activity observed for pentabromopseudilin is reported in Table 1.

Table 1. Antibacterial activity of pentabromopseudilin expressed as Minimum Inhibitory Concentration (MIC) or half maximal inhibitory concentration $\left(\mathrm{IC}_{50}\right)$ in $\mu \mathrm{M}$.

\begin{tabular}{ccc}
\hline Microorganisms & Pentabromopseudilin (1) & References \\
\hline Acinetobacter calcoaceticus & $>90.3 \mu \mathrm{M}$ & {$[19]$} \\
Bacillus brevis & $1.81 \mu \mathrm{M}$ & {$[19]$} \\
Bacillus subtilis & $1.81 \mu \mathrm{M}$ & {$[19]$} \\
MRSA (ATCC 43300) & $\left(\mathrm{IC}_{50}\right)=0.181 \mu \mathrm{M}$ & {$[20]$} \\
\hline
\end{tabular}

The introduction in the pentabromopseudilin of a carbonyl group between the phenyl group and the pyrrole moiety, i.e., compound 4 (Figure 1), entails an increase in antibacterial activity against Escherichia coli and Bacillus subtilis, whereas N-methylation is disadvantageous for the antibacterial activity $[19,21]$.

For pyoluteorin (2) activity against S. aureus, P. aeruginosa, E. coli and Pseudomonas vulgaris with MIC values of $11.39 \mu \mathrm{M}, 459 \mu \mathrm{M}, 22.79 \mu \mathrm{M}$ and $459 \mu \mathrm{M}$, respectively, is reported [22]. The study of Structure Activity Relationship (SAR) of the 2-aroyl-4,5-dihalopyrroles [22,23] has shown that: (i) the presence of one or more electron-withdrawing groups on the pyrrole is required for the antibacterial activity; (ii) the replacement of chlorine on the pyrrole ring with more electropositive halogens, such as bromine and iodine, produces less active compounds towards S. aureus and E. coli [22]; (iii) the replacement of chlorine atoms with nitro groups causes an increase of antibacterial activity [23]; (iv) the attendance on the phenyl ring of a $4-\mathrm{CF}_{3}, 2,5-\mathrm{diOH}$ or 2,4-diOH leads to compounds with better or comparable antibacterial activity with respect to pyoluteorin against $S$. aureus, with MIC values in the range $0.98-3.9 \mu \mathrm{g} / \mathrm{mL}$, but with only a weak activity on E. coli (MIC $>125 \mu \mathrm{g} / \mathrm{mL}$ ).

The acidity of the pyrrole NH group appeared to be important for the activity of this class of compounds; accordingly, the presence of a more electronegative group, such as the nitro group, which causes a significant increase in $\mathrm{NH}$ acidity, is associated with an improvement of microbiological activity, probably because it facilitates a stronger binding to the active site of the receptor target [23].

Another natural halogenated pyrrole derivative showing antimicrobic actity is the antibiotic pyrrolnitrin (5) (Figure 2), produced by Pseudomonas spp. [24-26], Myxococcus fulvus [27], and Enterobacter agglomerans [28]. It shows antibacterial activity against Gram-positive pathogens, in particular against certain Streptomyces species, such as S. antibioticus and S. violaceoruber (MIC $=0.89 \mu \mathrm{M}$ ), against fungal strains, such as Paecilomyces variotii and Penicillium puberulum (MIC in the range 8.9-26.9 $\mu \mathrm{M}$ ) [29], and against a range of mycobacteria, including Mycobacterium tuberculosis (MIC in the range 17.9-35.9 $\mu \mathrm{M}$ ) [30]. This compound was launched in 1966 as an antifungal OTC drug in Japan.

Studies on the mechanism of action of pyrrolnitrin showed that it probably blocks electron transfer between the dehydrogenases and the cytochrome components of the respiratory chain [29].

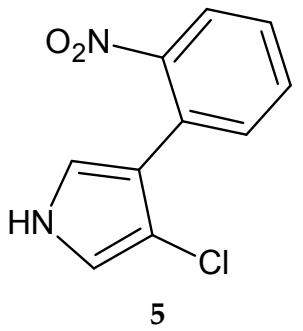

Figure 2. Structure of pyrrolnitrin 5. 


\section{Natural Pyrrolomycins}

Pyrrolomycins (PM) are polyhalogenated metabolites known for their potent antimicrobial properties [31], isolated from the fermentation broth of Actinosporangium and Streptomyces species [32-37]. The antibiotics of this family include pyrrolomycins A, B, C, D, E, G, H, I, J and dioxapyrrolomycin (Figure 3).<smiles>O=[N+]([O-])c1c[nH]c(Cl)c1Cl</smiles>

PM-A<smiles>O=C(c1cc(Cl)cc(Cl)c1O)c1[nH]c(Cl)c(Cl)c1Cl</smiles>

PM-D<smiles>O=[N+]([O-])c1c(Cc2cc(Cl)cc(Cl)c2O)[nH]c(Cl)c1Cl</smiles>

PM-B<smiles>Oc1c(Cl)cc(Cl)cc1-c1[nH]c(Cl)c(Cl)c1Cl</smiles>

PM-E<smiles>O=C(c1cc(Cl)c(Cl)[nH]1)c1cc(Cl)cc(Cl)c1O</smiles>

PM-C<smiles>O=[N+]([O-])c1c([C@@H]2OCOc3c(Cl)cc(Cl)cc32)[nH]c(Cl)c1Cl</smiles>

Dioxapyrrolomycin<smiles>O=[N+]([O-])c1c([C@H](O)c2cc(Cl)cc(Cl)c2O)[nH]c(Cl)c1Cl</smiles>

PM-G<smiles>COc1c(Cl)cc(Cl)cc1C(=O)c1cc(Cl)c(Cl)[nH]1</smiles>

PM-I<smiles>COc1c(Cl)cc(Cl)cc1[C@H](O)c1[nH]c(Cl)c(Cl)c1[N+](=O)[O-]</smiles>

PM-H<smiles>COc1c(Cl)cc(Cl)cc1C(=O)c1[nH]c(Cl)c(Cl)c1Cl</smiles>

PM-J

Figure 3. Structures of pyrrolomycins A, B, C, D, E, G, H, I, J and dioxapyrrolomycin.

Important structural features of the pyrrolomycins are: (i) their high halogenation degree, which is usually represented by chlorine substituents; and (ii) in some cases, the presence of a nitro group at the position 3 of the pyrrole ring. The antibacterial activity of these derivatives may be closely related to their halogen content, because it increases as the degree of halogenation $[38,39]$.

\section{Antibacterial Activity of Natural Pyrrolomycins}

Pyrrolomycins A and B are active against Gram-positive pathogens, such as S. aureus, S. epidermidis, S. faecalis, and Bacillus anthracis and Gram-negative bacteria, such as E. coli, Salmonella typhi, Klebsiella pneunioniae and Shigella sonnei with MIC values in the range of $0.55-69.1 \mu \mathrm{M}$ for PM-A, and in the range of $0.28-35.11 \mu \mathrm{M}$ for PM-B. The antibacterial activity 
of both pyrrolomycins A and B is comparable, although pyrrolomycin A is more active against Gram-negative bacteria and pyrrolomycin B against Gram-positive bacteria.

Pyrrolomycins C, D and E are active against Gram-positive pathogens such as S. aureus, S. faecalis and Bacillus anthracis, as reported in Table 2. Pyrrolomycins $\mathrm{C}$ and $\mathrm{E}$ are inactive against Gram-negative pathogens, such as E. coli, Salmonella typhi, Klebsiella pneunioniae and Shigella sonnei, whereas pyrrolomycin D showed a moderate activity with MIC values ranging from 4.34 to $34.78 \mu \mathrm{M}$.

Pyrrolomycins $\mathrm{C}$ and D are similar to pyoluteorin produced by Pseudomonas, but the better activity of pyrrolomycin D against Gram-positive bacteria is probably due to the introduction of a chlorine atom into pyrrole moiety. Pyrrolomycin D was the most active compound among the natural pyrrolomycins, being even more active than vancomycin when tested against $S$. aureus, S. epidermidis, E. faecalis, S agalactiae, L. monocytogenes, and B. subtilis with MIC values, in most of cases $\leqslant 0.002 \mu \mathrm{M}[40]$.

Dioxapyrrolomycin is primarily active against Gram-positive bacteria, as demonstrated by the MIC values in the range of $0.077-0.64 \mu \mathrm{M}$ for $S$. aureus and S. faecalis. The chirality and novel 1,3-dioxane ring may confer additional unique biological properties to this molecule in comparison to other members of the pyrrolomycin class [31]. The antibacterial activities of natural pyrrolomycins are summarized in Table 2.

Table 2. Antibacterial activities of natural pyrrolomycins.

\begin{tabular}{ccccccc}
\hline \multirow{2}{*}{ Organism } & \multicolumn{5}{c}{ MIC $(\mu \mathbf{M})$} \\
\cline { 2 - 7 } & PM-A & PM-B & PM-C & PM-D & PM-E & Dioxapyrrolomycin \\
\hline Staphylococcus aureus 209P JC-1 & 17.29 & 0.56 & 0.61 & $\leqslant 0.069$ & 5.07 & $0.077 \sim 0.64$ \\
Streptococcus faecalis ATCC 8043 & 34.53 & 1.09 & 1.2 & $\leqslant 0.069$ & 5.07 & 0.644 \\
Bacillus anthracis & 8.62 & 0.28 & 0.31 & $\leqslant 0.069$ & $\leqslant 0.16$ & - \\
Escherichia coli & 34.53 & 35.11 & $>307.72$ & 17.39 & $>325.18$ & $>329.87$ \\
Citrobacter freundii GN 346 & 34.53 & 35.11 & $>307.72$ & 17.39 & $>325.18$ & $>329.87$ \\
Salmonella typhi 0-901-W & 17.29 & 35.11 & $>307.72$ & 17.39 & $>325.18$ & - \\
Shigella sonnei EW 33 Type I & 34.53 & 35.11 & $>307.72$ & 34.78 & $>325.18$ & - \\
Klebsiella pneumoniae PCI 602 & 17.29 & 35.11 & $>307.72$ & 17.39 & $>325.18$ & $>329.87$ \\
Proteus vulgaris OX-19 & 34.53 & 35.11 & $>307.72$ & 4.34 & 20.32 & - \\
Serratia marcescens MB-3848 & 34.53 & 70.23 & $>307.72$ & 34.78 & $>325.18$ & $>329.87$ \\
Pseudomonas aeruginosa MB-3829 & 69.07 & 35.11 & $>307.72$ & 69.56 & $>325.18$ & $>329.87$ \\
Cryptococcus neoformans Cr-1 & 138.14 & 280.91 & $>307.72$ & 17.39 & $>325.18$ & - \\
Candida albicans & 552.55 & 280.91 & $>307.72$ & 278.23 & $>325.18$ & $>1319.48$ \\
Aspergillus fumigatus & 138.14 & 280.91 & $>307.72$ & 278.23 & $>325.18$ & $>1319.48$ \\
\hline
\end{tabular}

The pyrrolomycins G-H-I-J were obtained from cultures of Streptomyces fumanus [36]. Pyrrolomycin $\mathrm{G}$ and pyrrolomycin $\mathrm{H}$, together with dioxapyrrolomycin, are the only pyrrolomycins that possess a chiral center. The crystal structure the $N$-methyl derivative of dioxapyrrolomycin revealed an $\mathrm{S}$ absolute stereochemistry.

The pyrrolomycins G, H and J were tested against Gram-positive, S. aureus WT and MRSA, and the Gram-negative bacteria E. faecium VR, E. coli WT, and E. coli imp. The activities are summarized as MIC values in Table 3 [41].

Table 3. Antibacterial activities of pyrrolomycins G, H and J.

\begin{tabular}{cccc}
\hline \multirow{2}{*}{ Organism } & \multicolumn{3}{c}{ MIC $(\mu \mathbf{M})$} \\
\cline { 2 - 4 } & PM-G & PM-H & PM-J \\
\hline S. aureus WT & 21 & 2.6 & 2.6 \\
S. aureus MRSA & 21 & 5.1 & 5.3 \\
E. faecium VR & 21 & NT & NT \\
E. coli WT & $>300$ & $>300$ & $>300$ \\
E. coli imp & 86 & 10.3 & 21.4 \\
\hline \multicolumn{4}{c}{ NT $=$ not tested. }
\end{tabular}


Pyrrolomycins F1, F2a, F2b and F3 (Figure 4) were isolated from Actinosporangium vitaminophilum sp. nov. when bromide ions were added to the culture medium [42].

Pyrrolomycins F showed strong activities against Gram-positive bacteria including S. aureus, S. epidermidis [39], Streptococcus faecalis, and Bacillus anthracis, and only moderate activities against Gram-negative bacteria like E. coli, as shown in Table 4.

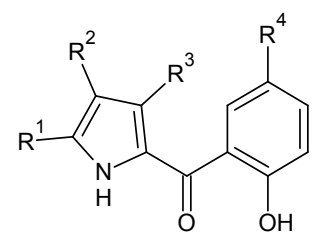

\begin{tabular}{cllll}
\hline Pyrrolomycin & $\mathbf{R}^{\mathbf{1}}$ & $\mathbf{R}^{\mathbf{2}}$ & $\mathbf{R}^{\mathbf{3}}$ & $\mathbf{R}^{\mathbf{4}}$ \\
\hline F1 & $\mathrm{Br}$ & $\mathrm{Br}$ & $\mathrm{Br}$ & $\mathrm{Br}$ \\
F2a & $\mathrm{Br}$ & $\mathrm{Cl}$ & $\mathrm{Br}$ & $\mathrm{Br}$ \\
F2b & $\mathrm{Cl}$ & $\mathrm{Br}$ & $\mathrm{Br}$ & $\mathrm{Br}$ \\
F3 & $\mathrm{Cl}$ & $\mathrm{Cl}$ & $\mathrm{Br}$ & $\mathrm{Br}$ \\
\hline
\end{tabular}

Figure 4. Chemical structures of pyrrolomycins F.

Table 4. Antibacterial activities of PM-F reported as MIC $(\mu \mathrm{M})$.

\begin{tabular}{|c|c|c|c|c|c|}
\hline \multirow{2}{*}{ Microorganisms } & \multicolumn{4}{|c|}{$\operatorname{MIC}(\mu \mathbf{M})$} & \multirow{2}{*}{ Reference } \\
\hline & F1 & F2a & F2b & F3 & \\
\hline S. aureus ATCC 29213 & $\leqslant 0.0019$ & $\leqslant 0.0019$ & $\leqslant 0.0019$ & $\leqslant 0.0019$ & [40] \\
\hline S. aureus ATCC 25923 & 0.04 & 0.04 & 0.04 & 0.04 & [40] \\
\hline S. epidermidis DSM 3269 & 0.012 & 0.012 & 0.012 & 0.012 & [40] \\
\hline S. epidermidis RP62A & 0.004 & 0.004 & 0.004 & 0.004 & {$[40]$} \\
\hline Staphylococcus aureus 209P JC-1 & $\leqslant 0.002$ & $\leqslant 0.002$ & $\leqslant 0.002$ & $\leqslant 0.002$ & [39] \\
\hline Streptococcus faecalis ATCC 8043 & 0.004 & 0.004 & 0.004 & 0.004 & [39] \\
\hline Bacillus anthracis & $<0.099$ & $<0.099$ & $<0.099$ & $<0.099$ & [39] \\
\hline Escherichia coli & $<0.099$ & $<0.099$ & $<0.099$ & $<0.099$ & [39] \\
\hline Citrobacter freundii GN 346 & $<0.099$ & $<0.099$ & $<0.099$ & $<0.099$ & [39] \\
\hline Salmonella typhi 0-901-W & 12.43 & 12.43 & 12.43 & 12.43 & [39] \\
\hline Shigella sonnei EW 33 Type I & 12.43 & 12.43 & 12.43 & 12.43 & [39] \\
\hline Klebsiella pneumoniae PCI 602 & 12.43 & 12.43 & 12.43 & 12.43 & [39] \\
\hline Proteus vulgaris OX-19 & 12.43 & 12.43 & 12.43 & 12.43 & [39] \\
\hline Serratia marcescens MB-3848 & 12.43 & 12.43 & 12.43 & 12.43 & [39] \\
\hline Pseudomonas aeruginosa MB-3829 & 6.22 & 6.22 & 6.22 & 6.22 & [39] \\
\hline Cryptococcus neoformans Cr-1 & 6.22 & 6.22 & 6.22 & 6.22 & [39] \\
\hline
\end{tabular}

Pyrrolomycins C, D, F1, F2a, F2b and F3 were also tested for their anti-staphylococcal biofilm activity. With the exception of pyrrolomycin $\mathrm{C}$, all tested compounds were active against all staphylococcal biofilms at the concentration of $1.5 \mu \mathrm{g} / \mathrm{mL}(4.17 \mu \mathrm{M}, 2.98 \mu \mathrm{M}, 3.27 \mu \mathrm{M}$, and $3.62 \mu \mathrm{M}$ for pyrrolomycin D, F1, F2a,b, and F3, respectively), the inhibition percentages being $>60 \%$ for all compounds, and, in many cases, $>80 \%$. At the lower concentration of $0.045 \mu \mathrm{g} / \mathrm{mL}$, pyrrolomycin $\mathrm{F} 3$ $(0.11 \mu \mathrm{M})$ showed the best activity with an inhibition percentage $>50 \%$ against all tested strains and the remarkable selectivity index (ratio between $\mathrm{IC}_{50}$ on human cell and antibiofilm concentration) of 1333 [39].

Toxicity studies in vivo have been carried out on JCL-ICR mice for dioxapyrrolomycin, which unfortunately was very toxic with an oral $\mathrm{LD}_{50}$ of $13 \mathrm{mg} / \mathrm{kg}$ [31]. The other natural pyrrolomycins were less toxic: pyrrolomycin $A$ and $B$ showed $L_{50}$ values of 21.2 and about $100 \mathrm{mg} / \mathrm{kg}$, respectively, when administered i.p. to JCL-ICR mice [37]; pyrrolomycins $C$ and $\mathrm{D}$ showed $\mathrm{LD}_{50}$ values of $50 \mathrm{mg} / \mathrm{kg}$ and $20 \mathrm{mg} / \mathrm{kg}$, respectively [35]. 


\section{Synthetic Pyrrolomycins}

Pentatomic nitrogenous heterocyclic compounds are widely described in the literature for a variety of biological activities [43-45] including the antibacterial activity [46-48]. This observation, combined with the interesting biological results observed with the natural pyrrolomycins, encouraged the synthesis of new analogs.

In 1973, Bailey et al. synthesized a series of compounds related to pyoluterin via three different synthetic routes: (i) acylation of pyrrole with the Grignard reagent; (ii) acylation with 4,5-dihalopyrrol-2-carbonyl chloride; and, (iii) base-catalyzed condensation of pyrrole with arylaldehydes. Compounds $\mathbf{6 a}-\mathbf{j}$ showed good in vitro antibacterial activities against a variety of pathogens (Table 5), but none was able to prevent mortality in mice infected with S. aureus or Klebsiella pneumoniae [22].

Table 5. In vitro antibacterial activity of compounds $\mathbf{6 a}-\mathbf{j}$.<smiles>[X]c1cc(C(=O)c2cccc(P)c2)[nH]c1[X]</smiles>

\begin{tabular}{ccccccc}
\hline \multirow{2}{*}{ Compound } & \multirow{2}{*}{$\mathbf{R}$} & \multicolumn{5}{c}{ Ga-j } \\
\cline { 3 - 7 } & & & S. aureus & P. aeruginos & E. coli & P. vulgaris \\
\hline $\mathbf{6 a}$ & $\mathrm{Cl}$ & $2,6-(\mathrm{OH})_{2}$ & 11.39 & 459.42 & 22.78 & 459.42 \\
$\mathbf{6 b}$ & $\mathrm{Br}$ & $2-\mathrm{Cl}$ & 42.92 & $>343.94$ & 343.94 & $>343.94$ \\
$\mathbf{6 c}$ & $\mathrm{Cl}$ & $3-\mathrm{Cl}$ & 28.41 & 227.66 & $>227.66$ & $>227.66$ \\
$\mathbf{6 d}$ & $\mathrm{Cl}$ & $4-\mathrm{F}$ & 60.45 & 484.33 & $>484.33$ & $>484.33$ \\
$\mathbf{6 e}$ & $\mathrm{Br}$ & $4-\mathrm{F}$ & 44.96 & 360.25 & $>360.25$ & $>360.25$ \\
$\mathbf{6 f}$ & $\mathrm{Cl}$ & $4-\mathrm{CF}_{3}$ & 10.06 & $>405.74$ & $>405.74$ & $>405.74$ \\
$\mathbf{6 g}$ & $\mathrm{Br}$ & $2,4,6-\left(\mathrm{CH}_{3}\right)_{3}$ & 42.04 & $>336.86$ & $>336.86$ & $>336.86$ \\
$\mathbf{6 h}$ & $\mathrm{Cl}$ & $2,5-(\mathrm{OH})_{2}$ & 3.6 & 459.42 & 459.42 & 229.71 \\
$\mathbf{6 i}$ & $\mathrm{Br}$ & $2,5-(\mathrm{OH})_{2}$ & 43.21 & 346.27 & 346.27 & 173.13 \\
$\mathbf{6 j}$ & $\mathrm{Cl}$ & $2,4-(\mathrm{OH})_{2}$ & 14.33 & $>459.42$ & 115.04 & $>459.42$ \\
\hline
\end{tabular}

Koyama et al. submitted a patent on triiodoallyl- or iodopropargyl-substituted heterocyclic aromatic compounds endowed with remarkable antibacterial and antifungal activities. The inventors changed the structure of pyrrolomycin A by introducing a triiodoallyl group (compounds $7 \mathbf{a}-\mathbf{p}, \mathbf{8 a}-\mathbf{c}$, 9a,b, 10a-d) or an iodopropargyl group (compounds 11a-1, 12a-c, 13, 14, 15, 16) to the nitrogen atom of the pyrrole ring in an attempt to obtain compounds more potent than pyrrolomycin A (Figure 5, Table 6). The new structures have been synthesized by reaction of an unsubstituted or substituted nitrogen-containing heterocyclic compound with a reactive derivative of a 2,3,3-triiodoallyl alcohol or a reactive derivative of a 3-iodopropargyl alcohol in the presence of a base in an inert organic solvent. All new compounds showed a good biological activity against various bacterial and fungi strains, with MICs ranging from $0.09 \mu \mathrm{g} / \mathrm{mL}$ to $>50 \mu \mathrm{g} / \mathrm{mL}$ [49].

Table 6. Substituents $R^{1}, R^{2}, R^{3}$ and $R^{4}$ of compounds $7-16$.

\begin{tabular}{cllll}
\hline Compound & $\mathbf{R}^{\mathbf{1}}$ & $\mathbf{R}^{\mathbf{2}}$ & $\mathbf{R}^{3}$ & $\mathbf{R}^{\mathbf{4}}$ \\
\hline $\mathbf{7 a}, \mathbf{1 1 a}$ & $\mathrm{Cl}$ & $\mathrm{Cl}$ & $\mathrm{NO}_{2}$ & $\mathrm{H}$ \\
$7 \mathbf{b}, \mathbf{1 1} \mathbf{b}$ & $\mathrm{Cl}$ & $\mathrm{H}$ & $\mathrm{NO}_{2}$ & $\mathrm{H}$ \\
$\mathbf{7 c}$ & $\mathrm{H}$ & $\mathrm{H}$ & $\mathrm{NO}_{2}$ & $\mathrm{H}$ \\
$\mathbf{7 d}$ & $\mathrm{Cl}$ & $\mathrm{Cl}$ & $\mathrm{COOC}_{2} \mathrm{H}_{5}$ & $\mathrm{H}$ \\
$\mathbf{7 e}$ & $\mathrm{Cl}$ & $\mathrm{Cl}$ & $\mathrm{COOCH}_{3}$ & $\mathrm{H}$ \\
\hline
\end{tabular}


Table 6. Cont.

\begin{tabular}{|c|c|c|c|c|}
\hline Compound & $\mathrm{R}^{1}$ & $\mathbf{R}^{2}$ & $\mathbf{R}^{3}$ & $\mathbf{R}^{4}$ \\
\hline $7 f$ & $\mathrm{Cl}$ & $\mathrm{H}$ & $\mathrm{COOC}_{2} \mathrm{H}_{5}$ & $\mathrm{H}$ \\
\hline $7 \mathrm{~g}$ & $\mathrm{H}$ & $\mathrm{COOC}_{2} \mathrm{H}_{5}$ & $\mathrm{H}$ & $\mathrm{H}$ \\
\hline $7 \mathrm{~h}$ & $\mathrm{H}$ & $\mathrm{COOCH}_{3}$ & $\mathrm{H}$ & $\mathrm{H}$ \\
\hline $7 \mathbf{i}$ & $\mathrm{H}$ & $\mathrm{Cl}$ & 3-Cl-2- $\mathrm{NO}_{2}-\mathrm{C}_{6} \mathrm{H}_{5}$ & $\mathrm{H}$ \\
\hline $7 \mathbf{j}$ & $\mathrm{H}$ & $3-\mathrm{Cl}-\mathrm{C}_{6} \mathrm{H}_{5}$ & $\mathrm{H}$ & $\mathrm{H}$ \\
\hline $7 k, 11 \mathrm{i}$ & $\mathrm{H}$ & $\mathrm{C}_{6} \mathrm{H}_{5}$ & $\mathrm{H}$ & $\mathrm{H}$ \\
\hline 71 & $\mathrm{Cl}$ & $\mathrm{Cl}$ & $\mathrm{NO}_{2}$ & $\mathrm{Cl}$ \\
\hline $7 \mathrm{~m}, 11 \mathrm{j}$ & $\mathrm{Cl}$ & $\mathrm{Cl}$ & $\mathrm{H}$ & $\mathrm{COOCH}_{3}$ \\
\hline $7 \mathrm{n}$ & $\mathrm{COOCH}_{3}$ & $\mathrm{H}$ & $\mathrm{Cl}$ & $\mathrm{H}$ \\
\hline $7 \mathrm{o}, 11 \mathrm{k}$ & $\mathrm{COOCH}_{3}$ & $\mathrm{H}$ & $\mathrm{H}$ & $\mathrm{H}$ \\
\hline $7 p, 111$ & $\mathrm{NO}_{2}$ & $\mathrm{H}$ & $\mathrm{H}$ & $\mathrm{H}$ \\
\hline $8 a, 12 a$ & $\mathrm{H}$ & - & $\mathrm{H}$ & $\mathrm{H}$ \\
\hline $8 b, 12 b$ & $\mathrm{NO}_{2}$ & - & $\mathrm{H}$ & $\mathrm{H}$ \\
\hline $8 c, 12 c$ & $\mathrm{H}^{-}$ & - & $\mathrm{NO}_{2}$ & $\mathrm{H}$ \\
\hline $9 a, 15$ & - & - & - & $\mathrm{H}$ \\
\hline $9 b$ & - & - & - & $\mathrm{CH}_{3}$ \\
\hline $10 a, 16$ & - & - & - & $\mathrm{H}$ \\
\hline $10 b$ & - & - & - & $\mathrm{CH}_{3}$ \\
\hline $10 \mathrm{c}$ & - & - & - & $\mathrm{C}_{6} \mathrm{H}_{5}$ \\
\hline $10 \mathrm{~d}$ & - & - & - & $\mathrm{NHCOCH}_{3}$ \\
\hline $11 \mathrm{c}$ & $\mathrm{H}$ & $\mathrm{NO}_{2}$ & $\mathrm{H}$ & $\mathrm{H}$ \\
\hline 11d & $\mathrm{Cl}$ & $\mathrm{Cl}$ & $\mathrm{H}$ & $\mathrm{Cl}$ \\
\hline $11 \mathrm{e}$ & $\mathrm{Br}$ & $\mathrm{Br}$ & $\mathrm{NO}_{2}$ & $\mathrm{H}$ \\
\hline $11 \mathrm{f}$ & $\mathrm{Cl}$ & $\mathrm{Cl}$ & $\mathrm{COOC}_{2} \mathrm{H}_{5}$ & $\mathrm{H}$ \\
\hline $11 \mathrm{~g}$ & $\mathrm{H}$ & $\mathrm{COOC}_{2} \mathrm{H}_{5}$ & $\mathrm{H}$ & $\mathrm{H}$ \\
\hline $11 \mathrm{~h}$ & $\mathrm{H}$ & $\mathrm{Cl}$ & $2-\mathrm{NO}_{2}-3-\mathrm{Cl}-\mathrm{C}_{6} \mathrm{H}_{5}$ & $\mathrm{H}$ \\
\hline 13 & $\mathrm{H}$ & $\mathrm{H}$ & $\mathrm{H}$ & $\mathrm{H}$ \\
\hline 14 & $\mathrm{H}$ & $\mathrm{H}$ & $\mathrm{H}$ & $\mathrm{H}$ \\
\hline
\end{tabular}<smiles>[R]c1c([R])c([R])n(CC(I)=C(I)I)c1[Z]</smiles>

7a-p<smiles>[R]c1nc([R])n(CC(I)=C(I)I)c1[Z7]</smiles>

8a-c<smiles>[3H]c1nnnn1CC(I)=C(I)I</smiles>

9a,b

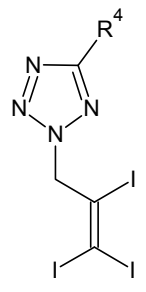

10a-d<smiles>[R]c1c([R])c([R])n(CC#CI)c1[R]</smiles>

$11 a-I$<smiles>[R]c1nc([R])n(CC#CI)n1</smiles>

14<smiles>[R]c1nc([R])n(CC#CI)c1[R]</smiles>

12a-c<smiles>[R]c1nnnn1CC#CI</smiles>

15<smiles>[R]c1nn(CC#CI)c([R])c1[R]</smiles>

13

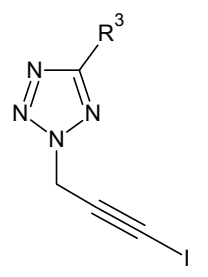

16

Figure 5. Structures of compounds 7-16. 
Schillaci et al. [50] reported the synthesis of bromo analogs of pyrrolomycins $17 \mathbf{a}-\mathbf{c}$ and 4 (Figure 6) by reaction of pyrrolylmagnesium bromide with 2-methoxybenzoyl chloride and subsequent demethylation of the methoxy group using anhydrous aluminum chloride to obtain the (2-hydroxyphenyl)(1H-pyrrol-2-yl)methanone. Finally, the bromination was carried out with cupric(II) bromide in organic solvent. Compounds $17 \mathrm{c}$ and 4 showed a remarkable antibacterial activity against S. aureus ATCC 25,923 (MIC values $=0.099$ and $0.017 \mu \mathrm{M}$, respectively); in particular, compound 4 was about 200 times more potent than the aminoglycoside, amikacin, against S. aureus [50]. The encouraging results led the authors to test compounds $17 \mathbf{a}-\mathbf{c}$ against ten clinical S. aureus strains, five susceptible and five resistant to methicillin [51]. Results, expressed as MIC values, showed that the antibacterial activity was correlated to the number of bromine atoms present on the molecule and the most active compound was the pentabromo analog 4 (Table 7). The authors continued the studies by testing, in vitro, compound 4 on seven reference Gram-positive bacterial strains including S. epidermidis, S. aureus, Listeria monocytogenes, Streptococcus agalactiae, Bacillus subtilis, and Enterococcus faecalis [38]. The activity of compound 4 was compared to the activity of vancomycin, and MIC and MBC values were determined. Compound 4 was found to be active against all tested strains with better MIC (ranging from 0.003 to $0.016 \mu \mathrm{M}$ ) and MBC (ranging from 0.63 to $21.4 \mu \mathrm{M}$ ) values than vancomycin, which showed MIC values ranging from 0.69 to $2.76 \mu \mathrm{M}$, and $\mathrm{MBC}$ values from 1.38 to $>5.5 \mu \mathrm{M}$.<smiles>[R]c1cc([R])c(O)c(C(=O)c2[nH]c([R])c([R])c2[R])c1</smiles>

17a-c, 4

\begin{tabular}{clllll}
\hline Compound & $\mathbf{R}^{\mathbf{1}}$ & $\mathbf{R}^{\mathbf{2}}$ & $\mathbf{R}^{\mathbf{3}}$ & $\mathbf{R}^{\mathbf{4}}$ & $\mathbf{R}^{5}$ \\
\hline $\mathbf{1 7 a}$ & $\mathrm{Br}$ & $\mathrm{Br}$ & $\mathrm{H}$ & $\mathrm{H}$ & $\mathrm{H}$ \\
$\mathbf{1 7 b}$ & $\mathrm{Br}$ & $\mathrm{Br}$ & $\mathrm{H}$ & $\mathrm{Br}$ & $\mathrm{H}$ \\
$\mathbf{1 7 c}$ & $\mathrm{Br}$ & $\mathrm{Br}$ & $\mathrm{H}$ & $\mathrm{Br}$ & $\mathrm{Br}$ \\
$\mathbf{4}$ & $\mathrm{Br}$ & $\mathrm{Br}$ & $\mathrm{Br}$ & $\mathrm{Br}$ & $\mathrm{Br}$ \\
\hline
\end{tabular}

Figure 6. Structures of derivatives $17 a-c$ and 4 .

Table 7. Minimum inhibitory concentration (MIC) in $\mu \mathrm{M}$ against clinical S. aureus strain susceptible or resistant to methicillin (s: methicillin susceptible strains; r: methicillin resistant strains).

\begin{tabular}{ccccc}
\hline S. aureus & \multicolumn{4}{l}{$\mathbf{( M I C )}$ in $\mu \mathbf{M}$} \\
\hline Strain & $\mathbf{1 7 a}$ & $\mathbf{1 7 b}$ & $\mathbf{1 7 c}$ & $\mathbf{4}$ \\
\hline 1s & 17 & 0.87 & 0.35 & 0.06 \\
2s & 17 & 0.87 & 0.17 & 0.06 \\
3s & 34.7 & 3.53 & 0.73 & 0.01 \\
4s & 17 & 0.87 & 0.17 & 0.06 \\
$5 \mathrm{~s}$ & 17 & 3.53 & 0.35 & 0.09 \\
1r & 8.69 & 0.87 & 0.07 & 0.01 \\
2r & 17 & 0.21 & 0.07 & 0.01 \\
3r & 17 & 0.42 & 0.17 & 0.03 \\
$4 \mathrm{r}$ & 17 & 1.76 & 0.17 & 0.01 \\
5r & 8.69 & 3.53 & 0.35 & 0.06 \\
\hline
\end{tabular}


In addition, compound 4 was also found to be active against preformed S. epidermidis and S. aureus biofilms with inhibition percentages ranging from 100 to 49.4 and 89 to 58, respectively, at concentrations of $0.08-2.5 \mu \mathrm{M}$.

In 2006, the Authors synthesized several 2-(2'-hydroxybenzoyl)pyrrole bromine derivatives (compounds 18a,b and 19a,b) to investigate whether the introduction of a keto or methylene spacer between the phenol and pyrroloyl moiety led to more active compounds [52]. Compounds $\mathbf{1 8 a}, \mathbf{b}$ have been synthesized by reaction of the (3,5-dibromo-2-methoxyphenyl)acetyl chloride with pyrrolylmagnesium bromide in anhydrous diethyl ether to obtain the 2-(3,5-dibromo-2-methoxyphenyl)1-(1H-pyrrol-2-yl)ethanone. Bromination with N-bromosuccinimide and the demethylation with boron tribromide in dry dichloromethane led to compounds $18 \mathbf{a}, \mathbf{b}$. Compounds $\mathbf{1 9} \mathbf{a}, \mathbf{b}$ were obtained by oxidation with selenium dioxide of the methylene group of the intermediates 1 -(4,5-dibromo-3- $R$ 1H-pyrrol-2-yl)-2-(3,5-dibromo-2-methoxyphenyl)ethanones and subsequent demethylation using anhydrous aluminum chloride in dry dichloromethane. The structural changes generated compounds with less antimicrobial activity with respect to compound 4; nevertheless, compounds 18a,b and $19 \mathbf{a}, \mathbf{b}$ resulted more active on $S$. aureus than the comparator amikacin, as shown in Table 8.

Table 8. Antimicrobial activity in vitro, MIC values expressed in $\mu \mathrm{M}$ for all strains tested.<smiles>[R]c1c(C(=O)Cc2cc(Br)cc(Br)c2O)[nH]c(Br)c1Br</smiles>

$18 \mathrm{a}, \mathrm{b}$<smiles>[R]c1c(Br)[nH]c(Br)c1C(=O)C(=O)c1cc(Br)cc(Br)c1O</smiles>

$19 a, b$

\begin{tabular}{cccc}
\multicolumn{5}{c}{$\mathbf{a}: \mathrm{R}=\mathrm{H} ; \mathbf{b}: \mathbf{R}=\mathrm{Br}, \mathbf{b}$} \\
\hline Compound & S. aureus ATCC $\mathbf{2 5 9 2 3}$ & E. coli ATCC 25922 & C. albicans ATCC 10231 \\
\hline $\mathbf{4}$ & 0.008 & 10.6 & $>21.4$ \\
$\mathbf{1 8 a}$ & 1.45 & $>24.1$ & $>24.1$ \\
$\mathbf{1 8 b}$ & 0.15 & 10.4 & $>20.9$ \\
$\mathbf{1 9 a}$ & 2.8 & $>23.5$ & $>23.5$ \\
$\mathbf{1 9 b}$ & 0.6 & $>20.5$ & $>20.5$ \\
Amikacin & 1.7 & 17 & n.t. \\
Amphotericin B & n.t. & n.t. & 0.16 \\
\hline
\end{tabular}

Moreover, the Authors reported the synthesis of new halogenated pyrroles related to pyrrolomycins F 20a-e to investigate their anti-Gram-positive and anti-staphylococcal activities and their ability to inhibit the formation of biofilms (Figure 7) [39,40,53].<smiles>[R9]c1[nH]c(C(=O)c2cc(Cl)cc(Cl)c2O)c(Br)c1[R]</smiles>

\begin{tabular}{clll}
\multicolumn{5}{c}{ 20a-e } & \\
\hline Compound & $\mathbf{R}_{\mathbf{1}}$ & $\mathbf{R}_{\mathbf{2}}$ & $\mathbf{R}_{\mathbf{3}}$ \\
\hline $\mathbf{2 0 a}$ & $\mathrm{Br}$ & $\mathrm{Br}$ & $\mathrm{Br}$ \\
$\mathbf{2 0 b}$ & $\mathrm{Br}$ & $\mathrm{Cl}$ & $\mathrm{Br}$ \\
$\mathbf{2 0 c}$ & $\mathrm{Cl}$ & $\mathrm{Br}$ & $\mathrm{Br}$ \\
$\mathbf{2 0 d}$ & $\mathrm{Cl}$ & $\mathrm{Cl}$ & $\mathrm{Br}$ \\
$\mathbf{2 0}$ & $\mathrm{Cl}$ & $\mathrm{Br}$ & $\mathrm{Cl}$ \\
\hline
\end{tabular}

Figure 7. Structures of compounds 20a-e. 
Compounds 20a-e were synthesized by reaction of pyrrolylmagnesium bromide with the 3,5-dichloro-2-methoxybenzoyl chloride. The introduction of halogen atoms on the pyrrole moiety was conducted by addition of the appropriate equivalents of $\mathrm{N}$-bromosuccinimide or $\mathrm{N}$-chlorosuccinimide in acetonitrile. Finally, the demethylation using anhydrous aluminum chloride in dry dichloromethane led to compounds 20a-e [53]. Results showed that the replacement of the $4^{\prime}$-bromo atom on the phenolic ring of pyrrolomycins $\mathrm{F}$ with two chloro atoms at the $3^{\prime}$ and $5^{\prime}$ position resulted in an increase of antibacterial activity against all strains tested, with MIC values ranging from $\leqslant 0.001$ to $12.5 \mu \mathrm{g} / \mathrm{mL}$ and $\mathrm{MBC}$ values ranging from $\leqslant 0.39 \mu \mathrm{g} / \mathrm{mL}$ to $12.5 \mu \mathrm{g} / \mathrm{mL}$.

Derivatives 20a and 20d were particularly interesting, showing MIC values against $S$. aureus, S. epidermidis, E. faecalis, S. agalactiae, L. monocytogenes and B. subtilis in the range $0.012-0.2 \mu \mathrm{M}$ and $0.007-0.2 \mu \mathrm{M}$ respectively. They were more potent than vancomycin, which showed MIC values ranging from 0.6 to $2.7 \mu \mathrm{M}$.

Compounds 4, 20a and 20d were also compared to some natural pyrrolomycins for their antistaphylococcal biofilm activity. Compound 20a showed a substantial antibiofilm activity at $0.09 \mu \mathrm{M}$ with an inhibition percentage $>50 \%$ against all tested staphylococcal strains. The activity of compound 20a was comparable to that exhibited by pyrrolomycin F3 and greater than that exhibited by pyrrolomycins C, D, F1, F2a and F2b. Interestingly, compound 20a had a selectivity index of 1666, and, therefore, it showed a slightly higher selectivity than pyrrolomycin F3 (selectivity index $=1333$ ). These data are particularly relevant because they refer to the antibiofilm activity. The selectivity indexes of compound 20a and pyrrolomycin F3 referred to their activities against the planktonic mode of growth were 7500 and 9600 , respectively. To our knowledge, synthetic analogues of pyrrolomicins have never been tested for their toxicity in animal models.

The antibiofilm activity of pyrrolomycins against $S$. aureus was also evaluated in terms of log reductions and their efficacy was compared to the efficacy of rifampicin, an antibiotic that is currently used in the clinic in the treatment of staphylococcal biofilm. [54] By using this different biofilm growth model, compound 20a and pyrrolomycin D were more active than rifampicin [39].

\section{Conclusions}

Resistant pathogens have become a serious threat worldwide and the use of new effective agents against drug-resistant bacteria is an urgent medical need. Such an emergence could be faced by revisiting old antibiotics and carefully monitoring their profile of efficacy, safety, and tolerability. Pyrrolomycins and other molecules are extremely interesting in terms of activity, in vitro and in vivo toxicity, and additional features including the ability to defeat intrinsic forms of resistance, such as biofilms [39]. Moreover, natural pyrrolomycin F3 and the synthetic analogue 20a have a very low cytotoxicity in human primary cell cultures, with a selectivity index $>1000$. This is remarkable if one considers that a good safety margin for a compound to be considered as a potential candidate for clinical development is a selectivity index $>200$ [55]. Another advantage of pyrrolomycins is related to their simple chemical synthesis, which allows us to easily obtain them although producing organisms are no longer available. It is concluded that pyrrolomycins and their synthetic derivatives are potential compounds for developing novel effective chemical countermeasures against pathogens. These molecules might represent the launching platform for the development of new antimicrobial agents. Data on the efficacy and safety of pyrrolomycins in animal models are urgently needed to determine whether these molecules deserve further consideration.

Acknowledgments: We wish to express our sincere thanks to Professor Ferdinando Nicoletti for many helpful hints and a great deal of patience in reviewing this document.

Author Contributions: The manuscript was written through the contributions of Stella Cascioferro, Maria Valeria Raimondi, Maria Grazia Cusimano, Demetrio Raffa, Benedetta Maggio, Giuseppe Daidone and Domenico Schillaci. All of the authors have approved the final version of the manuscript.

Conflicts of Interest: The authors declare no conflict of interest. 


\section{References}

1. Centers of Diseases Control and Prevention. Available online: http://www.cdc.gov/drugresistance/ pdf/ar-threats-2013-508.pdf (accessed on 2 December 2015).

2. Cascioferro, S.; Cusimano, M.G.; Schillaci, D. Antiadhesion agents against Gram-positive pathogens. Future Microbiol. 2014, 9, 1209-1220. [CrossRef] [PubMed]

3. Cascioferro, S.; Totsika, M.; Schillaci, D. Sortase A: An ideal target for anti-virulence drug development. Microb. Pathog. 2014, 77C, 105-112. [CrossRef] [PubMed]

4. Penesyan, A.; Gillings, M.; Paulsen, I.T. Antibiotic discovery: Combatting bacterial resistance in cells and in biofilm communities. Mol. Basel Switz. 2015, 20, 5286-5298. [CrossRef] [PubMed]

5. Cascioferro, S.; Schillaci, D. The Future of Antibiotic: From the Magic Bullet to the Smart Bullet. J. Microb. Biochem. Technol. 2014, 6, e118. [CrossRef]

6. Cascioferro, S.; Raffa, D.; Maggio, B.; Raimondi, M.V.; Schillaci, D.; Daidone, G. Sortase A Inhibitors: Recent Advances and Future Perspectives. J. Med. Chem. 2015. [CrossRef] [PubMed]

7. Escaich, S. Antivirulence as a new antibacterial approach for chemotherapy. Curr. Opin. Chem. Biol. 2008, 12, 400-408. [CrossRef] [PubMed]

8. Gill, E.E.; Franco, O.L.; Hancock, R.E.W. Antibiotic adjuvants: Diverse strategies for controlling drug-resistant pathogens. Chem. Biol. Drug Des. 2015, 85, 56-78. [CrossRef] [PubMed]

9. Payne, D.; Tomasz, A. The challenge of antibiotic resistant bacterial pathogens: The medical need, the market and prospects for new antimicrobial agents. Curr. Opin. Microbiol. 2004, 7, 435-438. [CrossRef] [PubMed]

10. Stewart, P.S. Mechanisms of antibiotic resistance in bacterial biofilms. Int. J. Med. Microbiol. 2002, 292, 107-113. [CrossRef] [PubMed]

11. Yang, L.; Liu, Y.; Wu, H.; Song, Z.; Høiby, N.; Molin, S.; Givskov, M. Combating biofilms. FEMS Immunol. Med. Microbiol. 2012, 65, 146-157. [CrossRef] [PubMed]

12. Schillaci, D.; Cascioferro, S. The Re-Discovering of Old Molecules to face the Antibiotic Crisis. J. Microb. Biochem. Technol. 2015, 7, e121. [CrossRef]

13. Cassir, N.; Rolain, J.-M.; Brouqui, P. A new strategy to fight antimicrobial resistance: The revival of old antibiotics. Front. Microbiol. 2014, 5, 551. [CrossRef] [PubMed]

14. Komura, S.; Kurahashi, K. Partial purification and properties of L-2,4-diaminobutyric acid activating enzyme from a polymyxin E producing organism. J. Biochem. 1979, 86, 1013-1021. [PubMed]

15. Dijkmans, A.C.; Wilms, E.B.; Kamerling, I.M.C.; Birkhoff, W.; Ortiz-Zacarías, N.V.; van Nieuwkoop, C.; Verbrugh, H.A.; Touw, D.J. Colistin: Revival of an Old Polymyxin Antibiotic. Ther. Drug Monit. 2015, 37, 419-427. [CrossRef] [PubMed]

16. Theuretzbacher, U.; Paul, M. Revival of old antibiotics: Structuring the re-development process to optimize usage. Clin. Microbiol. Infect. 2015, 21, 878-880. [CrossRef] [PubMed]

17. Falagas, M.E.; Vardakas, K.Z.; Roussos, N.S. Trimethoprim/sulfamethoxazole for Acinetobacter spp.: A review of current microbiological and clinical evidence. Int. J. Antimicrob. Agents 2015, 46, 231-241. [CrossRef] [PubMed]

18. Burkholder, P.R.; Pfister, R.M.; Leitz, F.H. Production of a pyrrole antibiotic by a marine bacterium. Appl. Microbiol. 1966, 14, 649-653. [PubMed]

19. Laatsch, H.; Renneberg, B.; Hanefeld, U.; Kellner, M.; Pudleiner, H.; Hamprecht, G.; Kraemer, H.P.; Anke, H. Structure-activity relationships of phenyl- and benzoylpyrroles. Chem. Pharm. Bull. 1995, 43, 537-546. [CrossRef] [PubMed]

20. Fehér, D.; Barlow, R.; McAtee, J.; Hemscheidt, T.K. Highly Brominated Antimicrobial Metabolites from a Marine Pseudoalteromonas sp. J. Nat. Prod. 2010, 73, 1963-1966. [CrossRef] [PubMed]

21. Masuda, K.; Suzuki, K.; Ishida-Okawara, A.; Mizuno, S.; Hotta, K.; Miyadoh, S.; Hara, O.; Koyama, M. Pyrrolomycin group antibiotics inhibit substance P-induced release of myeloperoxidase from human polymorphonuclear leukocytes. J. Antibiot. 1991, 44, 533-540. [CrossRef] [PubMed]

22. Bailey, D.M.; Johnson, R.E.; Salvador, U.J. Pyrrole antibacterial agents. 1. Compounds related to pyoluteorin. J. Med. Chem. 1973, 16, 1298-1300. [CrossRef] [PubMed]

23. Hughes, C.G.; Rees, A.H. Nitro analogs of pyoluteorins. J. Med. Chem. 1973, 16, 574-576. [CrossRef] [PubMed] 
24. Parry, R.; Nishinob, S.; Spain, J. Naturally-occurring nitro compounds. Nat. Prod. Rep. 2011, 28, $152-167$. [CrossRef] [PubMed]

25. Arima, K.; Imanaka, H.; Kousaka, M.; Fukuda, A.; Tamura, G. Studies on pyrrolnitrin, a new antibiotic. I. Isolation and properties of pyrrolnitrin. J. Antibiot. 1965, 18, 201-204. [PubMed]

26. Hamill, R.; Elander, R.; Mabe, J.; Gorman, M. Metabolism of tryptophans by Pseudomonas aureofaciens. V. Conversion of tryptophan to pyrrolnitrin. Antimicrob. Agents Chemother. 1967, 7, 388-396. [PubMed]

27. Gerth, K.; Trowitzsch, W.; Wray, V.; Höfle, G.; Irschik, H.; Reichenbach, H. Pyrrolnitrin from Myxococcus fulvus (Myxobacterales). J. Antibiot. 1982, 35, 1101-1103. [CrossRef] [PubMed]

28. Chernin, L.; Brand, A.; Ismailov, L.; Chet, I. Pyrrolnitrin Production by an Enterobacter agglomerans Strain with a Broad Spectrum of Antagonistic Activity towards Fungal and Bacterial Phytopathogens. Curr. Microbiol. 1996, 32, 208-212. [CrossRef]

29. El-Banna, N.; Winkelmann, G. Winkelmann Pyrrolnitrin from Burkholderia cepacia: Antibiotic activity against fungi and novel activities against streptomycetes. J. Appl. Microbiol. 1998, 85, 69-78. [CrossRef] [PubMed]

30. Di Santo, R.; Costi, R.; Artico, M.; Massa, S.; Lampis, G.; Deidda, D.; Pompei, R. Pyrrolnitrin and related pyrroles endowed with antibacterial activities against Mycobacterium tuberculosis. Bioorg. Med. Chem. Lett. 1998, 8, 2931-2936. [CrossRef]

31. Carter, G.T.; Nietsche, J.A.; Goodman, J.J.; Torrey, M.J.; Dunne, T.S.; Borders, D.B.; Testa, R.T. LL-F42248 alpha, a novel chlorinated pyrrole antibiotic. J. Antibiot. 1987, 40, 233-236. [CrossRef] [PubMed]

32. Koyama, M.; Kodama, Y.; Tsuruoka, T.; Ezaki, N.; Niwa, T.; Inouye, S. Structure and synthesis of pyrrolomycin A, a chlorinated nitro-pyrrole antibiotic. J. Antibiot. 1981, 34, 1569-1576. [CrossRef] [PubMed]

33. Kaneda, M.; Nakamura, S.; Ezaki, N.; Iitaka, Y. Structure of pyrrolomycin B, a chlorinated nitro-pyrrole antibiotic. J. Antibiot. 1981, 34, 1366-1368. [CrossRef] [PubMed]

34. Koyama, M.; Ezaki, N.; Tsuruoka, T.; Inouye, S. Structural studies on pyrrolomycins C, D and E. J. Antibiot. 1983, 36, 1483-1489. [CrossRef] [PubMed]

35. Ezaki, N.; Koyama, M.; Shomura, T.; Tsuruoka, T.; Inouye, S. Pyrrolomycins C, D and E, new members of pyrrolomycins. J. Antibiot. 1983, 36, 1263-1267. [CrossRef] [PubMed]

36. Charan, R.D.; Schlingmann, G.; Bernan, V.S.; Feng, X.; Carter, G.T. Dioxapyrrolomycin biosynthesis in Streptomyces fumanus. J. Nat. Prod. 2006, 69, 29-33. [CrossRef] [PubMed]

37. Ezaki, N.; Shomura, T.; Koyama, M.; Niwa, T.; Kojima, M.; Inouye, S.; Ito, T.; Niida, T. New chlorinated nitro-pyrrole antibiotics, pyrrolomycin A and B (SF-2080 A and B). J. Antibiot. 1981, 34, 1363-1365. [CrossRef] [PubMed]

38. Schillaci, D.; Petruso, S.; Sciortino, V. 3,4,5,3' ,5'-Pentabromo-2-(2'-hydroxybenzoyl)pyrrole: A potential lead compound as anti-Gram-positive and anti-biofilm agent. Int. J. Antimicrob. Agents 2005, 25, 338-340. [CrossRef] [PubMed]

39. Schillaci, D.; Petruso, S.; Raimondi, M.V.; Cusimano, M.G.; Cascioferro, S.; Scalisi, M.; La Giglia, M.A.; Vitale, M. Pyrrolomycins as potential anti-staphylococcal biofilms agents. Biofouling 2010, 26, 433-438. [CrossRef] [PubMed]

40. Schillaci, D.; Petruso, S.; Cascioferro, S.; Raimondi, M.V.; Haagensen, J.A.J.; Molin, S. In vitro anti-Gram-positive and antistaphylococcal biofilm activity of newly halogenated pyrroles related to pyrrolomycins. Int. J. Antimicrob. Agents 2008, 31, 380-382. [CrossRef] [PubMed]

41. Charan, R.D.; Schlingmann, G.; Bernan, V.S.; Feng, X.; Carter, G.T. Additional pyrrolomycins from cultures of Streptomyces fumanus. J. Nat. Prod. 2005, 68, 277-279. [CrossRef] [PubMed]

42. Ezaki, N.; Koyama, M.; Kodama, Y.; Shomura, T.; Tashiro, K.; Tsuruoka, T.; Inouye, S.; Sakai, S. Pyrrolomycins F1, F2a, F2b and F3, new metabolites produced by the addition of bromide to the fermentation. J. Antibiot. 1983, 36, 1431-1438. [CrossRef] [PubMed]

43. Raffa, D.; Maggio, B.; Raimondi, M.V.; Cascioferro, S.; Plescia, F.; Cancemi, G.; Daidone, G. Recent advanced in bioactive systems containing pyrazole fused with a five membered heterocycle. Eur. J. Med. Chem. 2015, 97, 732-746. [CrossRef] [PubMed] 
44. Maggio, B.; Raimondi, M.V.; Raffa, D.; Plescia, F.; Cascioferro, S.; Cancemi, G.; Tolomeo, M.; Grimaudo, S.; Daidone, G. Synthesis and antiproliferative activity of 3-(2-chloroethyl)-5-methyl6-phenyl-8-(trifluoromethyl)-5,6-dihydropyrazolo[3,4-f][1,2,3,5]tetrazepin-4-(3H)-one. Eur. J. Med. Chem. 2015, 96, 98-104. [CrossRef] [PubMed]

45. Wang, Y.; Mitchell-Ryan, S.; Raghavan, S.; George, C.; Orr, S.; Hou, Z.; Matherly, L.H.; Gangjee, A. Novel 5 -substituted pyrrolo[2,3-d]pyrimidines as dual inhibitors of glycinamide ribonucleotide formyltransferase and 5-aminoimidazole-4-carboxamide ribonucleotide formyltransferase and as potential antitumor agents. J. Med. Chem. 2015, 58, 1479-1493. [CrossRef] [PubMed]

46. Whalen, K.E.; Poulson-Ellestad, K.L.; Deering, R.W.; Rowley, D.C.; Mincer, T.J. Enhancement of antibiotic activity against multidrug-resistant bacteria by the efflux pump inhibitor 3,4-dibromopyrrole-2,5-dione isolated from a Pseudoalteromonas sp. J. Nat. Prod. 2015, 78, 402-412. [CrossRef] [PubMed]

47. Liu, J.-J.; Zhao, M.-Y.; Zhang, X.; Zhao, X.; Zhu, H.-L. Pyrazole derivatives as antitumor, anti-inflammatory and antibacterial agents. Mini Rev. Med. Chem. 2013, 13, 1957-1966. [CrossRef] [PubMed]

48. Duan, Y.-T.; Wang, Z.-C.; Sang, Y.-L.; Tao, X.-X.; Zhu, H.-L. Exploration of structure-based on imidazole core as antibacterial agents. Curr. Top. Med. Chem. 2013, 13, 3118-3130. [CrossRef] [PubMed]

49. Koyama, M.; Kai, F.; Tsuruoka, T.; Miyauchi, K.; Matsumoto, K.; Akita, E.; Inouye, S.; Niida, T. Heterocyclic Compounds and Antibacterial and Antifungal Compositions Containing the Same as Active Ingredients. EP0080051 A2, 1 June 1983.

50. Petruso, S.; Bonanno, S.; Caronna, S.; Ciofalo, M.; Maggio, B.; Schillaci, D. Oxidative halogenation of substituted pyrroles with $\mathrm{Cu}(\mathrm{II})$. Part IV. Bromination of 2-(2'-hydroxybenzoyl)pyrrole. A new synthesis of bioactive analogs of monodeoxypyoluteorin. J. Heterocycl. Chem. 1994, 31, 941-945. [CrossRef]

51. Schillaci, D.; Maggio, B.; Petruso, S. In vitro activity of synthetic bromo analogs of pyrrolmycins against clinical Staphylococcus aureus strains. Pharmazie 1996, 51, 64. [PubMed]

52. Raimondi, M.V.; Cascioferro, S.; Schillaci, D.; Petruso, S. Synthesis and antimicrobial activity of new bromine-rich pyrrole derivatives related to monodeoxypyoluteorin. Eur. J. Med. Chem. 2006, 41, 1439-1445. [CrossRef] [PubMed]

53. Raimondi, M.V.; Schillaci, D.; Petruso, S. Synthesis and anti-staphylococcal activity of new halogenated pyrroles related to Pyrrolomycins F. J. Heterocycl. Chem. 2007, 44, 1407-1411. [CrossRef]

54. Trampuz, A.; Zimmerli, W. Antimicrobial agents in orthopaedic surgery: Prophylaxis and treatment. Drugs 2006, 66, 1089-1105. [CrossRef] [PubMed]

55. Suto, M.J.; Domagala, J.M.; Roland, G.E.; Mailloux, G.B.; Cohen, M.A. Fluoroquinolones: Relationships between structural variations, mammalian cell cytotoxicity, and antimicrobial activity. J. Med. Chem. 1992, 35, 4745-4750. [CrossRef] [PubMed]

(C) 2015 by the authors; licensee MDPI, Basel, Switzerland. This article is an open access article distributed under the terms and conditions of the Creative Commons by Attribution (CC-BY) license (http://creativecommons.org/licenses/by/4.0/). 